Historia Slavorum Occidentis

2021, $\mathrm{nr} 4(31)$

ISSN 2084-1213

DOI: $10.15804 /$ hso210409

Ryszard Tomczyk (SzCzecin)

ORCID: 0000-0002-8490-9013

\title{
Cmentarz w Nawarii koło Lwowa. Z badań nad polskim dziedzictwem narodowym na utraconych ziemiach wschodnich
}

Keywords: cemeteries, history of Poles in the Eastern Territories of the former Polish Republic, Navaria near Lvov, the Polish national heritage

Słowa kluczowe: cmentarze, historia Polaków na ziemiach wschodnich dawnej Rzeczypospolitej, Nawaria pod Lwowem, polskie dziedzictwo narodowe

\begin{abstract}
Cemeteries are important sources of information on local and regional social history. Historic sepulchral objects, typically located in cemeteries (crosses, headstones, tombs, grave chapels), with well-preserved inscriptions and epitaphs, are also important source material in genealogical research. Today, of special importance is documenting the survived objects of sepulchral art in cemeteries located in the Eastern Territories lost by Poland. This article is an attempt at presenting the events and names of Poles who lived in Navaria near Lvov, a town later transformed into a village, based on the old crosses and headstones which have survived in the local cemetery, together with other source materials. There are few objects commemorating Poles in the historical part of the cemetery in Navaria where Poles were buried until the mid-1940s. In the past several decades, a majority of the Polish graves were destroyed. The remaining ones are testimony of Poles' presence in Navaria.
\end{abstract}

\section{Z dziejów miasta/wsi}

Poza obszarem metropolitalnym Lwowa, za nowymi wielkomiejskimi osiedlami, które powstały na terenie przyległych do miasta Sokolnik, następnie za Maliczko- 
wicami, rozciąga się zabudowa Nawarii. Dawniej, w czasach Pierwszej Rzeczypospolitej i zaboru austriackiego było to małe miasto. W okresie Drugiej Rzeczypospolitej była to duża wieś i jest tak po czasy obecne. Współcześnie Nawaria należy pod względem administracyjnym do rejonu pustomyckiego w obwodzie lwowskim.

Pierwsza pisemna informacja na temat Nawarii pochodzi z $1493 \mathrm{r}$. Według ustaleń dziewiętnastowiecznych lwowskich badaczy, głównie znanego krajoznawcy i historyka Antoniego Schneidera, Nawarię założyła rodzina Niwerów (Nawarów), którzy sprowadzili pierwszych osadników z Czech. W 1578 r. król Stefan Batory nadał Nawarii prawo magdeburskie. W przywileju zezwolił także mieszkańcom na prowadzenie działalności handlowej. W tym czasie w miasteczku działał młyn, mieszkało trzech kowali, kilku piekarzy, słodownik, krawiec, dziegciarze i kuśnierze $^{1}$. W miejscowości osiedlili się także Żydzi. Z czasem rozwinęła się działalność tkacka. Produkowano tutaj grube żaglowe płótno, z przędzy dostarczanej przez Żydów. Miejscowość jeszcze na początku XIX w. była znana z rękodzielniczej produkcji tkackiej. W 1758 r. król August III Sas nadał przywilej odbywania jarmarków, w wymiarze dziewięć razy w roku. Handlem bydła i płodami rolnymi zajmowali się głównie miejscowi Żydzi². W XIX w. obok miejscowości znajdowały się folwarki zwane Harajec i Kuska. Duża własność ziemska obok Nawarii (przysiólek Kawczem) w pierwszych dwóch dekadach XX w. należała do Feilera Breindela oraz I. Staufera. W okresie Drugiej Rzeczypospolitej dużym właścicielem ziemskim w Nawarii był K. Christmann. W pierwszej połowie XIX w. działała w miejscowości fabryka papieru ${ }^{3}$ Na pograniczu gruntów Nawarii i Glinnej w XIX w. funkcjonowała cegielnia, która zajmowała się także produkcją wapna. Należała do rodziny Gotliebów, przedsiębiorców pochodzenia żydowskiego. Przed pierwszą wojną światową dzierżawcą cegielni był Andrzej Raganowicz (24.11.1870-17.06.1918, pochowany na Cmentarzu Janowskim we Lwowie), budowniczy, współwłaściciel zakładu wyro-

1 Stownik geograficzny Królestwa Polskiego i innych krajów stowiańskich, t. XV, część II, Warszawa 1902, s. 372.

2 Żydzi z Nawarii dostarczali mięso i inne płody rolne głównie do Lwowa. Niektórzy z nich byli czasem karani za brak zgłoszenia sprzedawanego na rynku mięsa do ówczesnego lwowskiego nadzoru weterynaryjnego. Na przykład na początku stycznia $1859 \mathrm{r}$. zostało ukaranych trzech Żydów z Nawarii za niezgłoszenie do nadzoru weterynaryjnego oferowanej do sprzedaży na rynku lwowskim wołowiny. Kronika, Gazeta Lwowska, 5 I 1859, nr 3.

3 Stownik geograficzny Królestwa Polskiego i innych krajów stowiańskich, t. VI, Warszawa 1885, s. 936; H. Stupnicki, Geograficzno-statystyczny opis Królestwa Galicji i Lodomerii, Lwów 1864, s. 93. 
bów marmurowych i właściciel realności we Lwowie. Dyrektorem cegielni w czasach Drugiej Rzeczypospolitej był Józef Schlossman ${ }^{4}$.

Na mocy rozporządzenia lwowskiego Gubernium z 2 V 1815 r. w Nawarii została uruchomiona szkoła ludowa. Na przełomie lat pięćdziesiątych i sześćdziesiątych XIX w. nauczycielem w miejscowej szkole był Konstanty Niementowski. W połowie lat sześćdziesiątych Jan Zajączkowski, w kolejnych zaś latach Leon Modest Odzierzyński. Wówczas dozorcą szkolnym był mieszczanin Józef Biniarz. W 1864 r. do szkoły uczęszczało 52 dzieci (22 chłopców i 30 dziewczynek). W 1867 r. liczba uczniów wzrosła do 119 (62 chłopców i 57 dziewczynek)5. Do czasów pierwszej wojny światowej w Nawarii funkcjonowała dwuklasowa szkoła ludowa. W $1914 \mathrm{r}$. kierownikiem tej szkoły (nauczycielem kierującym) był Aleksander Kucharski. W szkole wówczas także pracowały nauczycielki Maria Kucharska i Bronisława Łaganówna ${ }^{6}$. W połowie XIX w. w Nawarii funkcjonowała poczta. W miasteczku był także niewielki szpital. Po wybudowaniu w drugiej połowie XIX w. linii kolejowej Lwów-Stryj (pierwotnie była to część kolei Arcyksięcia Albrechta), w odległości około $3 \mathrm{~km}$ od miasteczka, powstał na terenie sąsiedniej miejscowości Glinna, dworzec kolei żelaznej „Glinna-Nawaria”. Pomiędzy Nawarią a Glinną znajdował obszar dworski zwany Ferdynandówką. Do czasów drugiej wojny światowej był to duży folwark z reprezentacyjnym dwukondygnacyjnym pałacem, który został zniszczony we wrześniu 1939 r. Przed pierwszą wojną światową właścicielem folwarku był Stanisław Mars. W czasach Drugiej Rzeczypospolitej jego syn Franciszek Mars.

Nawaria pod względem administracyjnym w okresie autonomicznym zaboru austriackiego była gminą. Stan taki trwał nadal po odrodzeniu się Polski. Na podstawie ustawy scaleniowej, 1 VIII 1934 r. została utworzona duża gmina Nawaria, w której znalazły się także okoliczne wsie: Basiówka, Glinna, Hodowice, Leśniowice,

4 Józef Schlossman był pochodzenia żydowskiego, zginął tragicznie 5 I 1933 r. W tym dniu przy pomocy dynamitu pracownicy cegielni wysadzali ścianę w kamieniołomie (prawdopodobnie chodzi o bardzo znany kamieniołom w Nagórzanach obok Nawarii). Pozyskany materiał miał służyć do wypalania gliny. Jeden ze spadających głazów przygniótł Schlossmana. Zginał na miejscu. Pozostawił żonę i troje dzieci. Tragiczna śmierć dyr. fabryki, Wiek Nowy, 6 I 1933, nr 9470.

5 Szematyzm Szkót Ludowych zostających pod nadzorem Lwowskiego Konsystorza Metropolitalnego Obrzadku Eacińskiego na rok 1864, Lwów 1864, s. 14; Szematyzm Szkół Ludowych zostających pod nadzorem Lwowskiego Konsystorza Metropolitalnego Obrządku Łacińskiego na rok 1867, Lwów 1867, s. 14.

6 Szematyzm Królestwa Galicji i Lodomerii z Wielkim Księstwem Krakowskim, Lwów 1914, s. 804 . 
Maliczkowice, Miłoszowice, Mostki, Nagórzany, Podsadki, Polanka, Porszna, Pustomyty, Siemianówka7.

Zgodnie ze spisem ludności w 1880 r. w Nawarii było 880 mieszkańców oraz 67 na obszarze dworskim. Polaków obrządku rzymskokatolickiego było 498. Ukraińców obrządku greckokatolickiego było wówczas $36^{8}$. Pozostała ludność była pochodzenia niemieckiego (osadnicy z Austrii i innych krajów niemieckich) oraz żydowskiego. W kolejnych dziesięcioleciach liczba ludności wzrosła. W 1914 r. Nawaria liczyła1262 mieszkańców ${ }^{9}$. Do czasu ekspatriacji Polaków po drugiej wojnie światowej to oni stanowili większość mieszkańców Nawarii. Polacy mieszkający w Nawarii i okolicy zmuszeni w 1946 r. do wyjazdu do Polski pozostawili ojcowiznę. Jednak zachowywali ją przez kolejne dziesięciolecia w sercach ${ }^{10}$. Po drugiej wojnie światowej w Nawarii zostały nieliczne polskie rodziny i Polacy, członkowie rodzin polsko-ukraińskich.

W miejscowości istniała do czasów drugiej wojny światowej żydowska gmina wyznaniowa, która prowadziła księgi metrykalne ${ }^{11}$. Do miejscowej synagogi uczęszczali także Żydzi, mieszkający w okolicznych wsiach. Synagogi nie oszczędzali złodzieje. Padła ofiarą kradzieży m.in. w nocy 4 III 1899 r. Wówczas z bożnicy złodzieje wynie-

7 W 1931 r. w tych miejscowościach zamieszkiwało 15181 osób. Podczas okupacji niemieckiej w czasie drugiej wojny światowej gmina Nawaria została zniesiona. Wchodzące w jej skład miejscowości znalazły się w granicach nowych gmin Szczerzec i Pustomyty.

8 Stownik geograficzny, t. VI, s. 936.

9 J. Bigo, Najnowszy skorowidz wszystkich miejscowości z przysiółkami w Królestwie Galicyi, Wielkiem Księstwie Krakowskiem i Księstwie Bukowińskiem z uwzględnieniem wszystkich dotąd zaszłych zmian terytoryalnych kraju, Lwów 1914, s. 110.

10 Jedna z pieśni Kresowian, którzy osiedlili się po drugiej wojnie światowej w północno-zachodniej Polsce brzmiała: „Powiało chłodem na Wschodzie, / na Glimni został nasz dom, / i nasza dziecinna młodość, / która w sercu do dziś w nas jest, / Lwowie nasz drogi Lwowie, / Sokolniki, Nawaria i Glinna też, / tam zostały nasze korzenie, / każdy z nas to wie...”, cyt. za: E. Berendt, „Migrująca lokalnośc”. Niematerialne dziedzictwo kulturowe wobec kulturowej zmiany. Etnologiczne pytania o materię badawczą, Ochrona Zabytków (2014), nr 1, s. 24-25. 11 W okresie zaboru austriackiego nadzór nad gminami wyznaniowymi, szczególnie rejestrem ludności żydowskiej (urodzenia, śluby, zgony), prowadziło Namiestnictwo galicyjskie i starostwa powiatowe, np. starostwo powiatowe we Lwowie pismem z 10 XII 1909 r. poleciło przedstawicielowi gminy żydowskiej w Nawarii, który prowadził księgi metrykalne, aby wpisał do „księgi urodzonych w roku 1902 przy końcu rocznika pod bieżącą liczbą porządkową dosłownie co następuje: „Estera nieślubna córka Chaji Spitzmann urodziła się w Nawarii w roku tysiąc dziewięćsetnym drugim/1902”. Archiwum Główne Akt Dawnych w Warszawie (dalej: AGAD), sygn. 189. Gminy różne, powiaty różne (Akta stanu cywilnego). 
śli zasłonę wyszywaną złotą nicią, tałes (szal modlitewny), koszulki okrywające Torę i dwie korony Tory wykonane z kości słoniowej. Żandarmeria miejscowa prowadziła w tej sprawie śledztwo ${ }^{12}$. Obok Nawarii znajdował się cmentarz żydowski, który tak jak bożnica został zniszczony w czasie okupacji niemieckiej podczas drugiej wojny światowej. Wówczas też zostało zamordowanych wielu miejscowych Żydów. W okresie powojennym, około 1960 r., teren zniszczonego cmentarza żydowskiego został zalany wodą. Powstał staw ${ }^{13}$.

W Nawarii istniała parafia greckokatolicka z wybudowaną w 1872 r. niewielką, murowaną cerkwią. Świątynię wzniósł ówczesny miejscowy proboszcz ks. Paczowski. W cerkwi został umieszczony ikonostas pochodzący z $1730 \mathrm{r} .{ }^{14}$ Do parafii należeli grekokatolicy z Nawarii oraz z Glinnej, Hodowicy, Maliczkowic, Nagórzan i Wolicy. Współcześnie nadal istnieje cerkiew Zesłania Ducha Świętego, położona obok przelotowej przez Nawarię ulicy (droga Lwów-Szczerzec). Teren wokół cerkwi jest zadbany, ogrodzony metalowym płotem i obsadzony tujami. Przy cerkwi znajduje się dzwonnica parawanowa wybudowana w 1995 r. Przed głównym wejściem do świątyni wśród zieleni stoją ławki. Obok znajduje się duży drewniany krzyż. Z kolei po wschodniej stronie, za terenem cerkiewnym, obok przystanku autobusowego znajduje się kapliczka z figurą Matki Bożej, ogrodzona niskim metalowym płotkiem.

\section{Parafia i kościół rzymskokatolicki}

Polacy mieszkający do 1946 r. w Nawarii należeli do miejscowej parafii obrządku rzymskokatolickiego pod wezwaniem Wniebowzięcia Najświętszej Marii Panny. Parafia została utworzona przed 1600 r. Król Władysław IV Waza 6 V 1638 r. potwierdził we Lwowie przywileje dla parafii w Nawarii, które nadał jej Stanisław Bonifacy Mniszek, starosta ziem ruskich. W połowie XIX w. probostwo w Nawarii posiadało

\footnotetext{
12 Kronika, Kurier Lwowski, 6 III 1899, dodatek do nr 66.

13 Relacja Hanny Łozińskiej i Jewhenii Opoki, Nawaria 2019.

14 Ikonostas pochodził z klasztoru OO. Bazylianów w Dobromilu, który został ufundowany przez rodzinę Herburtów (prawdopodobnie przez Jana Szczęsnego Herburta, starostę dobromilskiego). Zakonnicy ikonostas usunęli z klasztoru. Przypadkowa natknął się na niego proboszcz greckokatolicki z Nawarii ks. Paczowski. Zainteresował się nim Mieczysław Ludwik Potocki, ziemianin, powstaniec Styczniowy i organizator urzędu konserwatora zabytków we Lwowie. Ikonostas został odnowiony ze środków z budżetu marszałka krajowego. Słownik geograficzny Królestwa Polskiego, t. VI, s. 936. J. Smirnow, Mieczysław Potocki - organizator urzędu konserwatorskiego w Galicji Wschodniej, Kurier Galicyjski, 31 V-16 VI 2014, nr 10.
} 
156 morgów dobrej jakości pól żytnich oraz 19 morgów ląk. Na początku lat siedemdziesiątych XIX w. kapitał parafii wynosił 5 tys. guldenów w obligacjach indemnizacyjnych i 3 tys. guldenów, zabezpieczonych na dobrach prywatnych. Roczny dochód plebani wynosił wówczas 773 guldenów. Pokrywało to wszystkie ponoszone przez parafię koszty oraz daniny i podatki ${ }^{15}$. Przez okres zaboru austriackiego w miasteczku istniał przy parafii rzymskokatolickiej fundusz ubogich, założony w 1771 r. przez Rocha Winiawskiego, ówczesnego właściciela okolicznych dóbr ziemskich. Miejscowi proboszczowie zarządzali środkami finansowymi tego funduszu.

Początkowo w parafii istniał drewniany kościól, który został zniszczony podczas najazdu Tatarów w 1621 r. Kościół został odbudowany w 1627 r. przez Elżbietę Leśniowską, żonę Jerzego Humnickiego, właściciela majątku w Zimnej Wodzie. Nowy drewniany kościół padł ofiarą ognia w 1630 r. Wtedy Elżbieta Humnicka ufundowała murowany kościół. Niestety murowana świątynia uległa zniszczeniu podczas najazdu kozacko-tatarskiego Bohdana Chmielnickiego w 1648 r. Ruiny kościoła zostały w 1739 r. rozebrane. Pozostało tylko prezbiterium. Do 1748 r. została wybudowana nowa świątynia, według projektu lwowskiego architekta Bernarda Meretyna. Jej fundatorem był chorąży przemyski Marcin Wieniawski, następnie jego syn Roch Wieniawski z żoną Urszulą z Szembeków. Świątynia została wzniesiona na podobieństwo bazyliki mniejszej z niższym prezbiterium. Większość wyposażenia dla barokowej świątyni zakupił kanonik lwowski i proboszcz w Nawarii Szczepan Mikulski $^{16}$. Ołtarze i ambonę zgodnie z ówczesnym nurtem rokokowym w sztuce, wykonał w latach 1763-1768 Piotr Polejowski, snycerz i architekt lwowski. Polejowski był także autorem projektu dzwonnicy parawanowej, wybudowanej w tym czasie obok kościoła. Wnętrze kościoła zostało ozdobione pilastrami i stiukowymi ornamentami. W prezbiterium ok. 1770 r. powstały malowidła Antonia Tavellia ze scenami biblijnymi. Tam też umieszczono kartusze herbowe fundatorów Rocha i Urszuli Wieniawskich. W prezbiterium została także umieszczona marmurowa płyta nagrobna Elżbiety Humnickiej. W drugiej połowie 1937 r. kościół został poddany pracom konserwatorskim. Wówczas położono nową blachę na dachu świątyni. Remont nadzorował ówczesny, młody wikariusz parafii w Nawarii ks. Franciszek Rozwód (1911-6 III 2016, pochowany we Wrocławiu) ${ }^{17}$. W okresie zaboru austriackiego i w Dru-

\footnotetext{
15 Kronika, Gazeta Lwowska, 28 III 1872, nr 73.

16 G. Rąkowski, Ziemia Lwowska. Przewodnik krajoznawczo-turystyczny po Ukrainie Zachodniej. Cześć III, Pruszków 2007, s. 441.

17 Ksiądz Franciszek Rozwód do wybuchu wojny polsko-niemieckiej w 1939 r. wybudował kaplicę w Glinnej i w Lipnikach. Kaplicę w Lipnikach poświęcił z późniejszym biskupem wro-
} 
giej Rzeczypospolitej, po czasy drugiej wojny światowej parafia w Nawarii należała do dekanatu Szczerzec. W okresie zaboru do parafii należeli zgodnie z danymi kościelnymi wierni z Nawarii, Leśniowic, Nagórzan, Podsadek, Porszny, Wolicy, Glinnej, Polanki i Mostek. Według doniesień „Gazety Lwowskiej” w 1872 r. do parafii należeli wyznawcy aż z dziesięciu okolicznych miejscowości, leżących w promieniu 1¹/4 mili o łącznej liczbie 1555 osób ${ }^{18}$. W 1913 r. została utworzona parafia w Pustomytach, w której znalazła się część wiernych z dotychczasowych parafii w Nawarii i Hodowicy. W 1936 r., gdy w Nawarii był długoletnim proboszczem (od 1905 r.) ks. Gabriel Trzebicki, było 698 wyznawców. W tym czasie Glinna liczyła 856 wiernych, Maliczkowice 498, Nagórzany 235, Podsadki 84, Porszna i Lipniki $148^{19}$.

Po drugiej wojnie światowej, po wyjeździe Polaków z Nawarii i innych miejscowości należących do parafii, kościół został zamknięty. Władze radzieckiej Ukrainy w świątyni urządziły magazyn, w którym przechowywano warzywa. W czasach niepodległej Ukrainy, w 1992 r., Kościół rzymskokatolicki odzyskał świątynię. Wówczas siłami miejscowych wyznawców obrządku rzymskokatolickiego został przeprowadzony remont wnętrza.

Współcześnie do kościoła, który znajduje się na wzniesieniu, przy wjeździe do Nawarii od strony Lwowa, prowadzi wąska droga o zniszczonej nawierzchni asfaltowej. Przed wejściem na teren kościelny zachowały się dwie stare akacje. Teren kościelny jest ogrodzony murem z białej cegły. Od bramy wejściowej do świątyni prowadzi wybrukowana aleja. Fasada kościoła wymaga remontu. Na zewnętrznych ścianach świątyni zachowały się barokowe elementy architektoniczne, m.in. charakterystyczne wazy na szczytach narożnych murów. W niszach na frontowej ścianie nad drzwiami wejściowymi brakuje figur, które pierwotnie tam były umieszczone. Na starych, drewnianych drzwiach wejściowych do kościoła, wzmocnionych kutymi z metalu listwami w formie kratownic, znajduje się tablica w języku polskim i ukraińskim. Napis na tablicy głosi: „Kościół Rzymsko-Katolicki P.W. św. Walentego". Z kolei na tablicy ogłoszeniowej, ustawionej przy wejściu na teren kościelny, są umieszczone informacje „parafii Wniebowzięcia Najświętszej Marii Panny w Nawarii". W rogu, po południowej stronie terenu kościelnego nadal znajduje się barokowa dzwonnica z jednym dzwonem, na którym jest data 1808 r. Na płaszczu dzwonu

cławskim ks. Wincentym Urbanem. A. Adamski, Wikariusz $z$ Kresów, Niedziela (edycja wroclawska), 44 (2011).

18 Kronika, Gazeta Lwowska, 28 III 1872, nr 73.

19 Schematismus Universi Saecularis er Regularis Cleri Archi Diaeceseos Metrol. Rit. Lat., Leopoli 1936, s. 168. 
pod ryngrafem Matki Bożej jest napis „Imię moje Maria Najświętsza wstawiaj się za mną". Dzwon został współcześnie wykonany w pracowni ludwisarskiej Jana Felczyńskiego w Przemyślu ${ }^{20}$. Przy murze, kilkanaście metrów od dzwonnicy został wyeksponowany zachowany fragment kamiennego obelisku, który stanowi część pomnika ustawionego w Nawarii w 1924 r. z napisem „Ojcom, synom i braciom poległym za wiarę i ojczyznę. Parafia Nawaria”. Przy murze, po północnej stronie kościoła zostało ułożonych kilkanaście fragmentów płyt kamiennych, pozbawionych inskrypcji i ornamentyki ${ }^{21}$. Obecnie w prezbiterium kościoła znajdują się nadal malowidła ścienne Antonia Tavellia z około 1770 r. oraz kartusze z herbami Wieniawa i Szembek Rocha i Urszuli Wieniawskich. Zachowal się także w prezbiterium marmurowy nagrobek Elżbiety Humnickiej z Leśniowskich z Zimnej Wody z jej popiersiem oraz herbami Gryf, Szaława, Jelita i Nieczuja. Z dawnego wyposażenia w kościele zachowały się również trzy drewniane ołtarze i cztery konfesjonały. Parafianie, opuszczając Nawarię w 1946 r., wywieźli część wyposażenia kościoła do Urazu na Dolnym Śląsku. Trafiły do miejscowego kościoła. Część przedmiotów została przekazana do muzeum w Olesku. Niektóre niewywiezione kościelne dzieła sztuki znalazły się w muzeum we Lwowie. Najcenniejsze to krucyfiks z głównego ołtarza, a także obraz Matki Bożej z Dzieciątkiem, który w drugiej połowie XVIII w. trafił do świątyni z katedry lwowskiej. 27 V 2017 r. odbyły się uroczyste obchody dwudziestopięciolecia odrodzonej parafii w Nawarii z udziałem arcybiskupa lwowskiego ks. Mieczysława Mokrzyckiego. Wówczas też do świątyni powróciła pozłacana kopia obrazu Matki Bożej z Dzieciątkiem. Kopię obrazu ufundowali parafianie z Urazu. Kościół Wniebowzięcia Najświętszej Marii Panny w Nawarii należy do najcenniejszych zabytków sakralnych w okolicy Lwowa. Na wprost kościoła, po drugiej stronie ulicy jest stary budynek. Dawniej była to plebania. Obecnie w tym budynku, który został wyremontowany w końcu drugiej dekady XXI w., mieści się przedszkole.

\section{Cmentarz katolicki w Nawarii}

W okresie zaboru austriackiego zgodnie z obowiązującym wówczas prawem sanitarnym został erygowany na wzgórzu, przy drodze z Nawarii do Hodowicy cmentarz katolicki. Przed pierwszą wojną światową na terenie cmentarza znajdowała się wy-

\footnotetext{
20 A. Adamski, Okolice Lwowa. Po kresowych bezdrożach (4 V 2017), www.biznesistyl.pl.

21 Prawdopodobnie są to pozostałości dawnego przykościelnego cmentarza z czasów Pierwszej Rzeczypospolitej.
} 
budowana przez miejscową gminę kaplica, do której zwożono ludzkie zwłoki, znalezione na okolicznych polach i w lasach ${ }^{22}$. Był to prawdopodobnie obiekt wzniesiony $\mathrm{z}$ drewna. Obecnie ta kaplica już nie istnieje. Utworzony w okresie zaboru cmentarz przy drodze z Nawarii do Hodowicy nadal jest użytkowany. W kolejnych dziesięcioleciach po drugiej wojnie światowej został znacznie rozszerzony. Współcześnie od kościoła do cmentarza prowadzi wąska droga asfaltowa. Biegnie obok zarośniętego roślinnością stawu.

Najstarsza część cmentarza, na której odbywały się pogrzeby do połowy lat czterdziestych XX w. znajduje się po południowej stronie wzgórza. Od drogi można na nią wejść przez niewielką boczną bramę. Na historycznej części cmentarza zachowało się kilka starych drzew liściastych o grubych pniach. Dawny cmentarz mieścił się na terenie o kształcie kwadratu o wymiarach około $100 \times 100 \mathrm{~m}$. Na tym terenie do dnia dzisiejszego są nieliczne krzyże metalowe i nagrobki, ustawiane do 1939 r., na których zachowały się inskrypcje w języku polskim. Znajdują się też fragmenty cokołów z piaskowca, pozbawione krzyży i figur Matki Bożej, a także inskrypcji. Nagrobki zostały zniszczone po drugiej wojnie światowej. Po przeprowadzonych oględzinach zachowanych nagrobków oraz ich fragmentów należy wnioskować, że większość ustawionych do 1939 r. na cmentarzu w Nawarii nagrobków była wykonana z jasnego piaskowca. Nagrobki te pochodziły przeważnie z licznych zakładów kamieniarskich w Demni ${ }^{23}$. Były to charakterystyczne nagrobki tzw. ludowe (głównie w formie kapliczek i „skałek” zwieńczonych krzyżami lub figurami Matki Bożej). Takie nagrobki były szeroko rozpowszechnione na cmentarzach wiejskich i małomiasteczkowych po południowo-zachodniej stronie Lwowa, od drugiej polowy XIX w. do $1939 \mathrm{r}$.

Zgodnie z Regestrum Mortuorum, prowadzonym przez parafię rzymskokatolicką w mieście Nawaria od lat osiemdziesiątych XVIII w. po drugą połowę XIX w. zmarła liczna rzesza członków miejscowych rodzin: Bamburowiczów, Baranów, Baranowskich, Barańskich, Barów, Bartoszów, Bereżańskich, Bieniaszów, Bliszczyńskich, Bokszyców, Buratyńskich, Burlikowskich, Chlebowskich, Chmielów, Chmielowskich, Chojeckich, Dąbrowskich, Dolińskich, Drągów, Dudziewiczów,

\footnotetext{
22 Zob. na przykład: Kronika, Kurier Lwowski, 22 IV 1908, nr 189.

23 We wsi Demnia koło Mikołajowa w powiecie żydaczowskim znajdowały się należące do Fundacji hr. Skarbka, huta szkła, cegielnia oraz kamieniołom, z którego wydobywano kamień pospolity, głównie piaskowiec. W miejscowych warsztatach kamieniarskich z tego pospolitego kamienia o odcieniu jasnym lub szarym masowo były wyrabiane do czasów drugiej wojny światowej nagrobki.
} 
Dzieciniaków, Foremnych, Fuksowiczów, Gawlickich, Gawlikowskich, Goleniowskich, Górewiczów, Huńków, Kaniaków, Królikowskich, Kunickich, Kowalczuków, Kramarzewskich, Kramarzów, Krochmalnych, Królikowskich, Kunickich, Kurowskich, Kuźnickich, Lachiewiczów, Lewińskich, Lisowskich, Łeszników, Łozów, Łuszków, Majewskich, Malinowskich, Mogiłków, Mrozów, Olbertów, Olszewskich, Opalińskich, Oszustów, Papanowiczów, Pawłowskich, Pichurów, Pikutów, Pietrawskich, Podwysockich, Rybaków, Sakiewiczów, Sarnickich, Skibów, Spetmańskich, Surmiaków, Szarowrzańskich, Szpetmanów, Szubartów, Szydłowskich, Szylarskich, Śliwińskich, Uchlińskich, Urbanów, Wanatów, Wenców, Wojdyłowiczów, Wojnickich, Woźniaków, Woźniackich, Woźnych, Wyszyńskich, Zatwarnickich, Ziembów, Żeleniowskich, Żiółeckich ${ }^{24}$. Wielu zmarłych z tych rodzin zajmowało się pracą w rolnictwie (w rejestrze zmarłych zapis w języku łacińskim - agricola). Z tego czasu na miejscowym cmentarzu nie zachowały się upamiętnienia w formie nagrobków.

Nieliczne wzmianki o zmarłych związanych z Nawarią znajdują się w dziewiętnastowiecznej prasie lwowskiej. Na przykład 28 X 1865 r. powiesił się w podlwowskiej wsi Grzęda, pochodzący z Nawarii parobek dworski Kazimierz Biłyk. Lekarz przybyły na miejsce zdarzenia stwierdził, że Biłyk „popełnił samobójstwo przy zupełnym pomieszaniu zmysłów" 25 . Nie jest pewne, czy został pochowany w Nawarii, czy na miejscowym cmentarzu w Grzędzie. 18 I 1868 r. powiesił się w Glinnej w jednej ze stodół parobek Andrzej Hodowicki. Opinia publiczna nie poznała powodów samobójstwa ${ }^{26}$. W 1869 r. wóz ciągnięty przez parę koni, którym powoził dwudziestodziewięcioletni Ukrainiec Konrad Czorny, bardzo szybko jechał przez Nawarię. Niebezpieczna jazda doprowadziła do tragedii. W pewnej chwili oś koła uderzyła w głowę znajdującą się obok drogi dwuletnią dziewczynkę. Nieznana z nazwiska dziewczynka w wyniku odniesionej rany zmarła na drugi dzień. Konrad Czorny za nieostrożną, szybką jazdę został skazany przez sąd lwowski 26 XI 1869 r. na 14 dni więzienia $^{27}$. 14 III $1872 \mathrm{r}$. zmarł w Nawarii miejscowy proboszcz parafii rzymskokatolickiej ks. Józef Kraulik. Przeżył 61 lat, z czego 36 lat w stanie kapłańskim ${ }^{28}$. W drugiej

24 AGAD, Księgi metrykalne parafii wyznania rzymskokatolickiego z terenu Archidiecezji Lwowskiej. Parafia Nawaria dekanat Szczerzec. Księgi metrykalne zgonów tylko dla miasta Nawaria, sygn. 993, 994. Ekstrakty z księgi metrykalnej urodzeń, ślubów i zgonów dla miasta Nawaria i wsi: Leśniowice, Nagórzany, Podsadki, Porszna, Wolica, Glinna, Polanka, Mostki, sygn. 998.

25 Kronika, Gazeta Lwowska, 11 XI 1865, nr 258.

26 Kronika, ibidem, 24 I 1868, nr 19.

27 Kronika, ibidem, 30 XI 1869, nr 274.

28 Kronika, ibidem, 28 III 1872, nr 73. 
połowie XIX w. na torach kolei Arcyksięcia Albrechta biegnących w pobliżu Nawarii dochodziło do samobójstw. Na przykład 28 VI 1874 r. pod Nawarią nieznany z nazwiska robotnik położył się na torach kolejowych i zginął pod kołami parowozu. Ciało nieznanego robotnika zostało przewiezione do szpitala w Nawarii ${ }^{29}$. Nie należy wykluczyć, że zostało pogrzebane w bezimiennej mogile na miejscowym cmentarzu.

W drugiej połowie XIX w., podobnie jak w poprzednich dziesięcioleciach, umieralność na terenie parafii w Nawarii była duża. Na przykład, zgodnie z Księgą Zmarłych na początku lat osiemdziesiątych XIX w., w Nawarii zmarli członkowie rodzin obrządku rzymskokatolickiego: Baranów, Bereżańskich, Boguszewskich, Chmielewskich, Czajków, Dzieciniaków, Hurkusiewiczów, Kaczorowskich, Kramarzów, Lisowskich, Michalików, Najwerów, Olszewskich, Pankiewiczów, Pawliszynów, Skibów, Widoczynów, Wyszyńskich. W Glinnej: Cymbałów, Dobrzynieckich, Drakowiczów, Dziedziców, Kilianów, Koziołów, Kramarzów, Mączków, Mulków, Olbertów, Olearników, Olszewskich, Pikułów, Skibów, Skowronów, Szargut, Tolmerów, Wyszyńskich, Żardeckich. W Leśniowicach: Dragańczuków, Karpiaków, Kochanowskich, Wichrowskich. W Mostkach: Kuźmińskich, Otonkowskich, Stankiewiczów, Wróblewskich. W Nagórzanach: Derbelów, Grabów, Ilkiewiczów, Kuźniewiczów, Malickich, Markowskich, Torbów. W Podsadkach: Bandrowskich, Czajków, Leśniaków, Ogrodników, Zwaryczów. W Porsznie: Anklewiczów, Bazików, Burianów, Golińskich, Łozów, Nowaków. W Wolicy: Czajków, Lisowskich, Pichurów, Surmiaków $^{30}$. Członkowie wymienionych rodzin zostali pochowani na cmentarzu parafialnym w Nawarii.

Na cmentarzu w Nawarii zachowały się nieliczne upamiętnienia Polaków pochodzące z końca XIX w. Najstarszy zachowany grób na historycznej części cmentarza, który upamiętnia fragment cokoła z szarego piaskowca pozbawiony krzyża, został usypany w 1890 r. Spoczywa w nim, zmarła w wieku 58 lat Małgorzata Goj (+1890). Niski kamienny cokól, na którym nie ma już krzyża, został ustawiony na miejscu spoczynku - zgodnie z zachowaną inskrypcją - zmarłych w jednym roku Katarzyny Sonsiady $(+1891)$ i Tomasza Sonsiady $(+1891)$. Błędnie zostały wyryte na cokole nazwiska obojga zmarłych. Prawidłowa pisownia tego nazwiska to Sąsiada. Zachował się nagrobek w formie kapliczki zwieńczonej figurą Matki Bożej wykonany z szarego piaskowca, który upamiętnia zmarłą w wieku 64 lat Agnieszkę Wszczyńską (†26.06.1898). W po-

29 Kronika, ibidem, 30 VI 1874, nr 146.

30 AGAD, Księgi metrykalne parafii wyznania rzymskokatolickiego z terenu Archidiecezji Lwowskiej. Parafia Nawaria, sygn. 1781. 
bliżu jej miejsca spoczynku znajduje się nagrobek z zachowanym krzyżem, wykonany także z szarego piaskowca, który został ustawiony na grobie zmarłego w wieku 36 lat Michała Wszczyńskiego (†1898). Na kolejnym nagrobku z szarego piaskowca z krzyżem nie zachowało się imię kobiety - [... ]a Skowron $(+1899)$. W środku historycznej części cmentarza leży na ziemi popękana plyta kamienna. Zachował się na niej fragment inskrypcji: $[\ldots]$ yoliarn $(+18[\ldots])$. Upamiętnia zmarłą osobę w wieku 53 lat. Tuż obok znajduje się zniszczona i zdewastowana kaplica grobowa o wymiarach w przyziemiu $2 \times 3 \mathrm{~m}$ i wysokości około $3 \mathrm{~m}$. Na dwuspadzistym dachu zachowało się stare oryginalne pokrycie $\mathrm{z}$ blachy. Na ścianach nie ma śladu inskrypcji i symboliki religijnej. Nie zachowały się także drzwi. Nisza grobowa została sprofanowana. Wśród sterty śmieci znajduje się w niej otwarta trumna. Współcześnie, kaplica stoi wśród krzewów i służy grabarzom, którzy składują w niej narzędzia.

$\mathrm{Z}$ początku XX w., po wybuch pierwszej wojny światowej, zachowały się również nieliczne upamiętnienia miejsc spoczynku mieszkańców parafii. W środku najstarszej części cmentarza stoi nagrobek z szarego piaskowca z krzyżem. Na krzyżu zachowała się figura Jezusa Chrystusa, który opiera stopy o czaszkę ludzką. Nagrobek upamiętnia tutaj pochowaną, zmarłą w wieku 64 lat Justynę Maślejczuk († I II 1902). Kolejny nagrobek z szarego piaskowca w formie kapliczki upamiętnia Marię Olbert (†1904). We wnęce kaplicznej zachowała się płaskorzeźba Matki Bożej. Wysoki nagrobek w formie kapliczki z zachowanym krzyżem stoi na miejscu spoczynku Jana Olearnika (1871-1905). W niszy kaplicznej umieszczona jest postać świętego. Po obu stronach krzyża zachowały się figury aniołów. Podobny pomnik w formie kapliczki został ustawiony na grobie Szczepana Najwera (1869-13 X 1906). Zachował się krzyż na cokole tego pomnika, na którym jest umieszczony Jezus Chrystus stojący na ciernistej koronie. Po obu stronach krzyża znajdują się klęczące anioły (jeden ma utrąconą głowę). Wysoki krzyż metalowy (tzw. „rurkowy”) na cokole wykonanym z otynkowanych cegieł jest na grobie Karola Baüera (†1909), który dożył sędziwego wieku. Zmarl, mając 97 lat. Nagrobek został wykonany z szarego piaskowca w formie kapliczki z zachowanym krzyżem, a w niszy kaplicznej figura świętego, który trzyma krzyż, stoi w miejscu, gdzie spoczywa Jan Smowion (1880-1910). W rodzinnym grobie spoczywa Michał Pankiewicz (1866-28 IV 1914). W tym grobie w późniejszych latach została pochowana jego córka Maria Pankiewicz (1894-18 X 1918) oraz żona Klara Pankiewicz (1875-6 I 1922). Na tym rodzinnym grobie stoi betonowy nagrobek z napisem „Najukochańszym rodzicom i siostrze. Dzieci”.

Na najstarszej części cmentarza zachowało się jedno upamiętnienie dziecka pochodzenia ukraińskiego, które zmarło w okresie zaboru austriackiego. Luźno leżąca 
na ziemi tabliczka, która pierwotnie była umieszczona na drewnianym lub metalowym krzyżu, upamiętnia w języku ukraińskim szesnastomiesięczne dziecko Stefanię Polanko (†16 VIII 1912).

W roku wybuchu pierwszej wojny światowej zmarł, zgodnie z zachowaną inskrypcją na charakterystycznym nagrobku w formie „skałki” pozbawionej krzyża, chłopiec Kazio Dziunia Gruby (†1914). Został pochowany nieopodal wspomnianej wyżej zniszczonej kaplicy nagrobnej. Prawdopodobnie ofiarą walk w okresie ofensywy rosyjskiej, jesienią 1914 r. była Józefa Iskierska (†1914). Upamiętnia ją nagrobek z szarego piaskowca w formie kapliczki z krzyżem. Na cokole znajduje się inskrypcja „zginęła od kul”. Krzyż metalowy z figurą Jezusa Chrystusa umieszczony na niskiej betonowej podstawie stoi na grobie Katarzyny Królikowskiej (†24 XII 1914). Na tabliczce jest informacja, że pochodziła z Nawarii. W dobrym stanie do czasów obecnych zachował się niewielki grobowiec, w którym spoczywa Stanisław Mars (1855-1915), właściciel folwarku obok Glinnej, dyrektor Towarzystwa Magazynowego we Lwowie. Był także aktywny na polu społecznym, jako radny lwowskiej rady powiatowej. Był członkiem wydziału powiatowego. Na górnej płycie grobowcowej został wyryty napis „urodził się w Limanowej, zmarł w Glinnej”. Pochodził z rodziny ziemiańskiej z okolic Limanowej. Był synem Antoniego Marsa i Franciszki z Żelechowskich. Miał dwóch braci. Kazimierz Mars (†1908) był właścicielem dóbr ziemskich, m.in. majątku w Pustomytach, gdzie zmarł. Drugi brat, Antoni Mars (1851-1918), był lekarzem, znanym położnikiem i ginekologiem, profesorem i rektorem Uniwersytetu Lwowskiego, działaczem Stronnictwa Prawicy Narodowej, posłem Galicyjskiego Sejmu Krajowego.

W środku historycznej części cmentarza znajduje się częściowo zagłębiony w ziemi nagrobek $w$ formie kapliczki, pozbawiony krzyża. Upamiętnia zmarłego w wieku 46 lat Jakuba Szpelmawskiego (†1916). Z okresu pierwszej wojny światowej zachował się jeszcze jeden pochówek. W grobie rodzinnym spoczywa zmarły w wieku 23 lat Bronisław Najwer $(+1916)$. Po dziesięciu latach został tutaj też pochowany jego ojciec, zmarły w wieku 60 lat Jan Najwer $(+1926)$. Na tym grobie stoi nagrobek w formie wysokiej „skałki” z krzyżem. Na cokole zachowała się charakterystyczna tablica inskrypcyjna, umieszczona na kotwicy. Symbol kotwicy jest rzadko spotykanym elementem sztuki sepulkralnej na cmentarzach pod Lwowem.

$\mathrm{Na}$ cmentarzu w Nawarii nie zachowały się upamiętnienia miejsc spoczynku poległych polskich obrońców Lwowa w czasie walk z Ukraińcami w latach 1918-1919. Według danych opublikowanych w połowie lat dwudziestych XX w. przez Józefa Białynię-Chołodeckiego i Adama Nechaya na cmentarzu w tym czasie znajdowały się czte- 
ry mogiły polskich żołnierzy poległych w wojnie polsko-ukraińskiej ${ }^{31}$. Zgodnie z wykazem poległych obrońców Lwowa zawartym w wydanej w 1926 r. we Lwowie książce W obronie Lwowa i Kresów Wschodnich. Polegli od 1-go listopada 1918 do 30 czerwca $1919 r$. na cmentarzu w Nawarii zostało pochowanych co najmniej pięciu polskich żołnierzy poległych w walkach z Ukraińcami w końcu kwietnia i w pierwszej dekadzie maja 1919 r. 27 IV 1919 w okolicy Nawarii poległ szer. Józef Kałamarz, legionista z czasów pierwszej wojny światowej. Został pochowany na miejscowym cmentarzu ${ }^{32}$. 2 V 1919 r. poległ w walce koło Nawarii szer. Ignacy Zaliszewski. Pochodził z Płocka. Spoczął na miejscowym cmentarzu ${ }^{33}$. 5 V 1919 r. zginął w Nawarii szer. Władysław Trześniowski. Tego samego dnia zginął w Nawarii szer. Feliks Bigos z 4. kompanii 1. batalionu Pułku Radomskiego. Obaj zostali także pochowani na miejscowym cmentarzu ${ }^{34} .9$ V 1919 r. poległ pod Nawarią szer. Feliks Rigoz. Został pochowany na miejscowym cmentarzu ${ }^{35}$. W tym czasie większa liczba poległych polskich żołnierzy (co najmniej 13) została pochowana na cmentarzu wojskowym $\mathrm{z}$ okresu pierwszej wojny światowej, znajdującym się przy drodze z Nawarii do Glinnej ${ }^{36}$. Na tym cmentarzu zostali także pochowani żołnierze ukraińscy. Współcześnie cmentarz wojskowy, oddalony ponad kilometr od obecnych zabudowań Nawarii jest zdewastowany. Polegli w walkach z Ukraińcami pod Nawarią zostali też pochowani na Kwaterze Obrońców Lwowa i Kresów Wschodnich na Cmentarzu Janowskim i na Cmentarzu Obrońców Lwowa. Po zakończeniu walk, w kolejnych latach Drugiej Rzeczypospolitej część z pochowanych na cmentarzu w Nawarii i na cmentarzu wojskowym pod Glinną została ekshumowana i pochowana na Cmentarzu Obrońców Lwowa.

Na terenie cmentarza w Nawarii zachowało się więcej całych nagrobków lub ich fragmentów upamiętniających pochowanych Polaków w okresie Drugiej Rzeczypospolitej. Niski nagrobek, na którym został utrącony krzyż, stoi na grobie zmarłego

31 J. Białynia-Chołodecki, Z dziejów oblężenia i odsieczy Lwowa w latach 1918-1920, [w:] Kalendarz powszechny „Haliczanin” na rok Pański 1925, Lwów 1925, s. 91; A. Nechay, Zwycięskie Termopyle, [w:] W obronie Lwowa i Kresów Wschodnich. Polegli od 1-go listopada 1918 do 30 czerwca 1919 r., Lwów 1926, s. 48.

32 W obronie Lwowa, s. 101.

33 Tamże, s. 162.

34 Tamże, s. 79, 151.

35 Tamże, s. 135.

36 Ciężkie walki o Nawarię i Glinną toczyły się 20 IV 1919 r. Wówczas żołnierze z Grupy Wielkopolskiej rozpoczęli natarcie na te miejscowości, wspierani przez artylerię. Nawaria i Glinna zostały zdobyte kosztem 19 zabitych, 137 rannych i 18 zaginionych żołnierzy. 
w wieku 20 lat Szczepana Markera $(+1919)$. W tym grobie został także pochowany Paweł Marker (†1927). W wieku 34 lat zmarł Michał Mulka († 1 II 1920). Na jego grobie stoi nagrobek z szarego piaskowca z zachowanym krzyżem. Nagrobek w kształcie kapliczki z utrąconym krzyżem znajduje się na grobie Michała Kiliana (1856-25 IV 1922). Nagrobek z zachowanym krzyżem upamiętnia Wiktorię Molę (1881-1924). W wieku 59 lat zmarła Maria Stolba (†18 III 1924). Na jej grobie stoi nagrobek w kształcie kapliczki z figurą Matki Bożej. Nagrobek w formie „skałki” zwieńczonej figurą Matki Bożej stoi na grobie rodzinnym, w którym pierwsza spoczęła w młodym wieku Gienia Pawlaczek (1913-23 I 1924). Później została pochowana w tym grobie jej matka Maria Pawlaczek (1888-1939). Wysoki obelisk wykonany z otynkowanej cegły został postawiony na grobie Kazimiery Kozieł (13 X 1891-8 XII 1925). Na tablicy umieszczonej na obelisku zachowała się inskrypcja: „Choć odeszłaś w świat nieznany daleki, lecz w sercu moim żyć będziesz na wieki. Mąż”. Leżący na ziemi fragment nagrobka w kształcie kapliczki upamiętnia Józefa Zasiadę (†1927). W tym samym roku zmarł Edmund Fierich (1860-1927), miejscowy leśniczy lasów państwowych. Jego miejsce spoczynku upamiętnia figura Matki Bożej, która stoi na kuli i nogą przyciska węża. Figura jest umieszczona na cokole wykonanym z szarego piaskowca. Do czasów współczesnych dotrwała bez głowy, która została utrącona. Kamienny nagrobek z utrąconym krzyżem stoi na grobie Jana Tesznara (1832-1927). Dwa nagrobki upamiętniają zmarlych w 1929 r. W środku historycznej części cmentarza, w gęstych krzakach jest nagrobek w formie kapliczki z figurą Matki Bożej. Upamiętnia zmarłego w wieku 57 lat Józefa Grzecznika (†1929). Z kolei nagrobek z lastrico stoi na grobie rodzinnym, w którym spoczywa Rudolf Torba (2 I 1913-10 VIII 1929). Jak głosi zachowana inskrypcja był „studentem Szkoły Technicznej we Lwowie”. Na nagrobku - poza kamienną tablicą inskrypcyjną - we wrześniu 2019 r. leżała luźno owalna metalowa tabliczka z nazwiskiem Rudolfa Torby, która pierwotnie wisiała na drewnianym lub metalowym krzyżu. Po latach w tym grobie została pochowana jego matka Anna Torba z Kramerów (1889-1944). Kapliczka z krzyżem została ustawiona na grobie zmarłego w wieku 68 lat Antoniego Woźniaka (†1930). W niszy kaplicznej, w dolnej części tego nagrobka zachowały się dwie figury modlących się kobiet. Betonowy krzyż z tabliczką stoi na grobie, w którym spoczywa zmarły w wieku 47 lat Franciszek Pankiewicz († 9 XI 1931). Z kolei nagrobek w formie kapliczki z krzyżem stoi na grobie Michała Klimowickiego (1901-1932). W niszy kaplicznej na tym nagrobku znajduje się figura niewiasty trzymającej miecz i tarczę. U podnóża krzyża są umieszczone figury dwóch żałobnic. Na zniszczonym nagrobku wykonanym z cegieł, z których odpadał tynk i nie ma inskrypcji, we wrze- 
śniu 2019 r. leżała luźno owalna tabliczka z krzyża drewnianego lub metalowego, upamiętniająca zmarłą w wieku 64 lat Katarzynę Bokrzyc (†28 I 1933). Grób zmarłej w wieku 63 lat Antoniny Najwerowej († 8 II 1933) przykrywa kamienna płyta $\mathrm{z}$ dużym krzyżem po środku. Z kolei zmarłą w wieku 69 lat Zofię Morawską ( $+10 \mathrm{~V}$ 1934). upamiętnia wysoki nagrobek zwieńczony figurą Matki Bożej. Współcześnie nagrobek ten jest pomalowany na biały kolor. Nagrobek z lastrico stoi w miejscu spoczynku zmarłego w wieku 66 lat Szymona Waliczaka (†3 VII 1935). Kolejny nagrobek w kształcie kapliczki z utrąconym krzyżem, gdzie zachowała się w niszy kaplicznej figura kobiety z mieczem i tarczą stoi na grobie zmarłego w wieku 63 lat Michała Kocuły (†1936). Kocuła pochodził z Hodowicy. Figura Matki Bożej zachowała się na cokole z szarego piaskowca na miejscu spoczynku Józefa Najwera (1874-1936). Podobny nagrobek z figurą Matki Bożej znajduje się na grobie Honoraty Lberi $(+1936)$. Zachowany w dobrym stanie nagrobek z piaskowca z charakterystyczną płaskorzeźbą klęczącej niewiasty upamiętnia Emilię Kandlową (1864-1937). Nagrobek w formie skałki z zachowanym krzyżem stoi na miejscu spoczynku zmarłego w wieku 73 lat Michała Woźnego (†1937). Wraz z nim została pochowana w czasie okupacji radzieckiej podczas drugiej wojny światowej, zmarła w wieku 62 lat wdowa po nim Marcelina Woźna (†8 V 1940). „Skałka” z utrąconym krzyżem (kamienny krzyż z tego nagrobka z figurą Jezusa Chrystusa i ornamentem roślinnym stoi oparty o cokół) upamiętnia zmarłego w wieku 18 lat Michała Olberta (†1938). Na tym nagrobku wokół owalnej tablicy z inskrypcją został umieszczony ornament roślinny. Obok tablicy są także wizerunki dwóch aniołów. Następna „skałka” z zachowanym krzyżem z figurą Jezusa Chrystusa upamiętnia zmarłego w wieku 25 lat Michała Szmyla (†1938). Na cokole znajduje się tablica inskrypcyjna stylizowana na otwartą księgę. Wokół księgi znajduje się ornament roślinny. Kolejna „skałka”, na której zachowała się figura Matki Bożej, upamiętnia zmarłą w wieku 68 lat Marię Kisił (†1938). Krzyż metalowy z zachowaną owalną tabliczką stoi na grobie Józefy Królikowskiej (1861-12 V 1938). Na tabliczce jest napis „Tu spoczywa nasza ukochana Babcia”. W środku historycznej części cmentarza, w dużej kępie krzaków zachował się wysoki nagrobek w formie kapliczki, zwieńczonej figurą Matki Bożej. Spoczywa tutaj Maria Markier (1867-5 I 1939). Z roku wybuchu drugiej wojny światowej zachowały się jeszcze cztery upamiętnienia osób pochowanych na cmentarzu w Nawarii. Niski nagrobek z figurą modlącego się anioła zachował się na grobie rodzeństwa, które zmarło w 1939 r., ośmioletniego Czesia Sussela i trzyletniego Bogusia Sussela. Byli dziećmi Michaliny i Edwarda Susselów. Kolejna skałka z figurą Matki Bożej, współcześnie pomalowana na biały kolor, stoi na miejscu spoczynku zmarłej w wieku 25 lat Marii 
Andrujasik (†1939). Krzyż metalowy na grobie ziemnym, otoczony betonową ramą, która współcześnie jest częściowo zniszczona, upamiętnia zmarłą na początku wojny polsko-niemieckiej w 1939 r. Spoczywa tutaj Bronisława Skowron (†3 IX 1939). Po latach została też w tym grobie pochowana Anna Bednarska (†5 I 1963). Duży nagrobek w formie skałki został postawiony na grobie zmarłego ks. Gabriela Trzebickiego (1870-1939), proboszcza parafii rzymskokatolickiej w Nawarii. Długoletni proboszcz Trzebicki w ostatnim okresie życia bardzo poważnie chorował na cukrzycę. Od lipca 1937 r. większość obowiązków w parafii wykonywał za chorego proboszcza wikariusz ks. Franciszek Rozwód ${ }^{37}$. Niewielka skałka z krzyżem upamiętnia rodzeństwo, dwuletnią Niunię i dziesięcioletnią Krysię Gruby. Obie dziewczynki zmarły na początku drugiej wojny światowej, w jednym dniu - 8 X 1939 r. Na tablicy umieszczonej na pomniku zachowała się inskrypcja „Jeszcze nie rozkwitło, już ich zerwano, tak Bóg rozkazał, Boga słuchano”.

Na najstarszej części cmentarza zachowało się kilka nagrobków wykonanych z szarego piaskowca, które upamiętniają Ukraińców w ich języku, zmarłych w okresie Drugiej Rzeczypospolitej. Wśród nich znajduje się nagrobek, który upamiętnia proboszcza parafii greckokatolickiej w Nawarii i dziekana szczerzeckiego Joana Strzelbickiego $(1856-1925)^{38}$.

Na najstarszej części cmentarza w Nawarii znajduje się kilkanaście nagrobków lub ich fragmentów, które zostały ustawione na grobach Polaków do 1939 r. Nie zostały na tych nagrobkach umieszczone daty, inskrypcje w języku polskim są zaś w znacznym stopniu uszkodzone. Na przykład wysoki nagrobek w formie kapliczki upamiętnia zmarłego w wieku 57 lat Józefa Goja[... ]. Z kolei niski nagrobek, także stylizowany na kapliczkę z krzyżem został ustawiony na grobie Laury Lubu [...] [...] stima (1879-5 V 19 [...]. Kolejna kapliczka zwieńczona figurą anioła upamiętnia Kazimierza Kudybę. Na tym nagrobku nie zostały umieszczone daty. Nagrobek z utrąconym krzyżem i zniszczoną inskrypcją stoi na grobie Marii [... ]. Kolejny

37 Krótko przed wybuchem wojny we wrześniu 1939 r. ks. Rozwód został przeniesiony do parafii w Bóbrce. A. Adamski, Wikariusz z Kresów; Bogu zawdzięczam swoje życie, tamże, 2013, nr 43.

38 Według mieszkanek Nawarii i Maliczkowic, sióstr Hanny Łozińskiej z Podolaków i Jewhenii Opoki z Podolaków, które mają polskie korzenie (mężów miały Ukraińców), rzymskokatolicki ks. Gabriel Trzebicki i greckokatolicki ks. Joan Strzelbicki byli braćmi. Taką informację przekazali im pamiętający obu duchownych przedwojenni miejscowi mieszkańcy, w tym ojciec Michał Podolak, który do wybuchu drugiej wojny światowej był pracownikiem Banku Zachodniego w Warszawie. Podolak w okolicy Nawarii w okresie Drugiej Rzeczypospolitej miał dziewięć morgów ziemi, pasiekę i sad. Relacja. 
nagrobek w formie kapliczki z krzyżem, pomalowany współcześnie na jasno zielony kolor stoi na grobie Józefa $S[. .$.$] . Pęknięty kamienny krzyż na stopniowanym coko-$ le, na narożach z ostrosłupami (takie pomniki zachowały się na Cmentarzu Łyczakowskim i Janowskim we Lwowie) stoi na miejscu spoczynku Stanisława Knauera (9 V 1889-[... ]). Przewrócony na ziemię nagrobek w formie kapliczki z nieczytelną inskrypcją w języku polskim upamiętnia osobę zmarłą w 1929 r. Na kolejnym przewróconym nagrobku, także $\mathrm{w}$ formie kapliczki, zachowało się imię zmarłego - Franciszek [...] i data śmierci (†1937). W środku historycznej części cmentarza, w dużej kępie krzewów zachowała się ustawiona na niskim cokole figura klęczącego anioła. Spoczywa tutaj zmarly w wieku trzech lat Roch Najwer ([ ... ]). Na kolejnym zachowanym pomniku w formie skałki z krzyżem znajduje się tablica inskrypcyjna, otoczona ornamentem roślinnym, na której nie zostały umieszczone daty. Spoczywa tutaj małżeństwo: zmarła w wieku 68 lat Helena Kolarska oraz zmarły w wieku 74 lat Józef Kolarski. Nagrobek w formie kapliczki, zwieńczony krzyżem zachował się na grobie małżeństwa Piotra i Marii Szewczuków. Na frontowej ścianie pomnika obok imion i nazwiska nie ma dat. Prawdopodobnie przed 1939 r. zmarli Jan i Aniela Wrona oraz Franciszek i Maria Szumoczkowie. Spoczywają we wspólnym grobie, na którym w okresie powojennym został postawiony nagrobek z lastriko. W ostatnich latach został ustawiony nowy nagrobek stylizowany na dawną skałkę z figurą Matki Bożej na grobie, w którym zostali pochowani członkowie rodziny Pichur. Niestety na nowym nagrobku nie umieszczono imion i dat. Pochowani tutaj członkowie rodziny Pichur zgodnie z inskrypcją na nagrobku „Proszą o Anioł Pański”. Na terenie historycznej części cmentarza znajduje się jeszcze kilka zachowanych pomników lub ich fragmentów, na których zostały całkowicie zniszczone inskrypcje. Duży krzyż metalowy stoi na grobie, który jest obwiedziony ramą betonową. Spoczywają tutaj Maria i Konstanty Barabaszowie. Także na tabliczce umieszczonej na krzyżu nie ma dat. Poza tym krzyżem znajduje się jeszcze około 20 starych krzyży żeliwnych lub metalowych (tzw. „krzyży rurkowych”), na których nie ma już tabliczek z inskrypcją. Trzy takie zardzewiałe metalowe krzyże, wyrwane z ziemi, stały we wrześniu $2019 \mathrm{r}$. oparte o drzewa, przy bocznym wejściu na historyczną część cmentarza.

Skąpe informacje na temat Polaków zmarłych na terenie parafii w Nawarii w okresie Drugiej Rzeczypospolitej zamieściła ówczesna lwowska prasa. Nietypowe zdarzenie opisał wiosną 1935 r. „Wiek Nowy”. Według gazety wówczas zmarła we Lwowie 64-letnia mieszkanka Nawarii Anna Fita. Przebywała we Lwowie u swojej córki. 26 III 1935 r. miała wracać do domu w Nawarii, ale w tym dniu została potrącona przez tramwaj na ul. Gródeckiej. W ciężkim stanie została przewieziona 
do szpitala powszechnego, gdzie zmarła 2 IV 1935 r. Anna Fita została pomyłkowo rozpoznana jako Pelagia Skibowa ze Zniesienia. Rodzina Skibowej pochowała ją na cmentarzu w Zniesieniu. Sprawa wyszła na jaw kilka dni później, gdy córka Anny Fity rozpoznała rzeczy na posterunku policji, gdy szukała matki. Tymczasem Skibowa wróciła do Zniesienia, co wywołało duże poruszenie wśród mieszkańców i wstrząs w rodzinie ${ }^{39}$.

Nieliczne upamiętnienia pochowanych zachowały się z okresu okupacji radzieckiej i niemieckiej w czasie drugiej wojny światowej. Poza wcześniej wspomnianymi nagrobkami upamiętniającymi Marcelinę Woźną (+8 V 1940) oraz Annę Torbę z Kramerów (1889-1944) zachowała się charakterystyczna „skałka” zwieńczona krzyżem na miejscu spoczynku Marii Olechowskiej (1881-1940). Na cokole tego nagrobka, nad i pod tablicą z inskrypcją, znajduje się stylizacja roślinna, w tym róże. W wieku 86 lat zmarła Agnieszka Królikowska (†1940). Upamiętnia ją nagrobek w formie „skałki”, zwieńczony figurą Matki Bożej. Na ziemi leży przewrócony nagrobek w formie kapliczki z utrąconym krzyżem, który pierwotnie stał w miejscu spoczynku zmarłego w wieku 74 lat Jana Hurkasiewcza (+1940). W grobie rodzinnym spoczywa zmarly w wieku 72 lat Walenty Olechowski (†10 IV 1940). Wraz $\mathrm{z}$ nim została pochowana po latach jego żona, zmarła w wieku 84 lat Ewa Olechowska (†21 IX 1964). Na tym grobie stoi betonowy nagrobek, postawiony wczasach radzieckiej Ukrainy. Kolejny nagrobek w formie skałki zwieńczonej krzyżem upamiętnia zmarłą w wieku 61 lat Antoninę Najwer $(+1941)$. Na tym nagrobku, nad i pod tablicą inskrypcyjną został umieszczony ornament roślinny. Nagrobek w formie kapliczki z krzyżem zachował się na miejscu spoczynku, zmarłego w wieku 74 lat Franciszka Machana (†1941). Nagrobek został wystawiony przez żonę, o czym świadczy zachowany na tablicy napis „Dla męża Ludwika Machan”. Kolejna „skałka” z krzyżem została ustawiona na grobie zmarłego w wieku 33 lat Jana Pańkiewicza (†30 VI 1941). Zginął w czasie, gdy wojska niemieckie zajmowały Lwów. W tym grobie został pochowany prawdopodobnie jego brat, który zmarł także w wieku 33 lat - Szczepan Pańkiewicz (†19 IV 1944). Na tablicy znajduje się napis „polegli śmiercią tragiczną". Nieznane są okoliczności ich śmierci.

Po ekspatriacji większości Polaków w 1946 r. ci, którzy pozostali na miejscu, po swej śmierci zostali pochowani na miejscowym cmentarzu, przeważnie „wśród swoich" - na jego części historycznej. W okresie radzieckiej Ukrainy zmarł Michał Ekiert (1887-1955). Wraz z nim została pochowana żona Michalina Ekiert (1903- 
-1979). Upamiętnia ich nagrobek z lastrico. Krzyż metalowy stoi na grobie, w którym spoczywa Jan Kasprowicz (1870-1956) i jego żona Katarzyna Kasprowicz (1873-1960). Podobny krzyż metalowy jest na grobie, w którym zostało pochowane małżeństwo Michalina Barabasz (15 III 1890-24 X 1964) i Andrzej Barabasz (10 IX 1877-13 I 1970). W tym grobie została pochowana także Cecylia Zajączkowska (26 VIII 1923-24 VIII 1973). W latach siedemdziesiątych XX w. został wybudowany na starej części cmentarza duży grobowiec. Jest on otynkowany, ma surową formę. Nie ma na nim elementów architektury sakralnej czy ornamentyki roślinnej. Jedynie jest płyta z inskrypcją w języku polskim. Spoczywają w nim Stanisław Olechowski (25 VIII 1921-7 XII 1966) oraz Jan Nowak (30 XI 1908-27 VI 1971). Tabliczka na krzyżu metalowym upamiętnia Jadwigę Aniszewską-Kasprowicz (1911-1990). W okresie niepodległej Ukrainy na historycznej części cmentarza w Nawarii zostały usypane kolejne mogiły, w których spoczęli miejscowi Polacy. Inskrypcja w języku polskim znajduje się na nowym nagrobku, który został ustawiony na grobie rodzinnym. Spoczywają w tym grobie Maria Nowak (8 XII 1914-26 II 1999) oraz Janina Olechowska (16 IX 1946-25 VI 2013) i Czesław Olechowski (22 I 1938-14 X 2014). Nowy nagrobek, nawiązujący w swej formie do dawnych nagrobków - na wysokim postumencie stoi figura Matki Bożej - został ustawiony na miejscu spoczynku Olgi Pichur (1921-2002). Nagrobek z lastrico został ustawiony na miejscu spoczynku Marii Siemieniec (10 II 1960-11 XI 2009) i Wiktora Siemieńca (15 II 1960-17 VI 2011). Na historycznej części cmentarza w Nawarii, wśród grobów usypanych w ostatnich dziesięcioleciach, są takie, w których spoczywają osoby pochodzenia polskiego upamiętnione w języku ukraińskim. W ten sposób została upamiętniona na nagrobku m.in. Józefa Olberta (3 V 1927-2 XII 1994). Obok grobowca, w którym spoczywają Jan Nowak i Stanisław Olechowski, stoi nagrobek upamiętniający spoczywającą tutaj Ivannę (Janinę) Staszkiw z Olechowskich (22 V 1917-26 VIII 2000). Napis na jej nagrobku jest także w języku ukraińskim.

W kolejnych dziesięcioleciach po drugiej wojnie światowej zostały erygowane nowe części cmentarza, które są kilkakrotnie większe od części historycznej. Powojenne części cmentarza są pozbawionę zadrzewienia. Rosną na nich nieliczne krzewy ozdobne. Najnowsza część, na której są sadowione groby w ostatnich latach, rozciąga się wzdłuż drogi w kierunku Hodowicy. Tutaj została wybudowana w latach dziewięćdziesiątych XX w. kaplica cmentarna. Na częściach cmentarza, które zostały erygowane po drugiej wojnie światowej, nie ma upamiętnień w języku polskim na nagrobkach. Współcześnie cmentarz jest administrowany przez miejscowe władze samorządowe. 


\section{Bibliografia}

Adamski A., Okolice Lwowa. Po kresowych bezdrożach (4 V 2017), www.biznesistyl.pl. Adamski A., Wikariusz z Kresów, Niedziela (edycja wrocławska), 44 (2011). Archiwum Główne Akt Dawnych w Warszawie, Księgi metrykalne parafii wyznania rzymskokatolickiego z terenu Archidiecezji Lwowskiej. Parafia Nawaria dekanat Szczerzec. Księgi metrykalne zgonów tylko dla miasta Nawaria, sygn. 993, 994. Archiwum Główne Akt Dawnych w Warszawie, Księgi metrykalne parafii wyznania rzymskokatolickiego z terenu Archidiecezji Lwowskiej. Ekstrakty z księgi metrykalnej urodzeń, ślubów i zgonów dla miasta Nawaria i wsi: Leśniowice, Nagórzany, Podsadki, Porszna, Wolica, Glinna, Polanka, Mostki, sygn. 998.

Archiwum Główne Akt Dawnych w Warszawie, Księgi metrykalne parafii wyznania rzymskokatolickiego z terenu Archidiecezji Lwowskiej. Parafia Nawaria, sygn. 1781.

Archiwum Główne Akt Dawnych w Warszawie, sygn. 189. Gminy różne, powiaty różne (Akta stanu cywilnego).

Berendt E., „Migrująca lokalność”. Niematerialne dziedzictwo kulturowe wobec kulturowej zmiany. Etnologiczne pytania o materię badawcza, Ochrona Zabytków (2014), nr 1, s. 19-30.

Białynia-Chołodecki J., Z dziejów oblężenia i odsieczy Lwowa w latach 1918-1920, [w: Kalendarz powszechny „Haliczanin” na rok Pański 1925, Lwów 1925.

Bigo J., Najnowszy skorowidz wszystkich miejscowości z przysiótkami w Królestwie Galicyi, Wielkiem Księstwie Krakowskiem i Księstwie Bukowińskiem z uwzględnieniem wszystkich dotąd zaszłych zmian terytoryalnych kraju, Lwów 1914.

Kronika, Gazeta Lwowska, 5 I 1859, nr 3.

Kronika, Gazeta Lwowska, 11 XI 1865, nr 258.

Kronika, Gazeta Lwowska, 28 III 1872, nr 73.

Kronika, Kurier Lwowski, 6 III 1899, dodatek do nr 66.

Kronika, Kurier Lwowski, 22 IV 1908, nr 189.

Nechay A., Zwycięskie Termopyle, [w:] W obronie Lwowa i Kresów Wschodnich. Polegli od 1-go listopada 1918 do 30 czerwca 1919 r., Lwów 1926.

Pochowana nieboszczka pod fatszywym nazwiskiem, Wiek Nowy, 13 IV 1935, nr 10151.

Rąkowski G., Ziemia Lwowska. Przewodnik krajoznawczo-turystyczny po Ukrainie Zachodniej. Cześć III, Pruszków 2007.

Relacja Hanny Łozińskiej i Jewhenii Opoki, Nawaria 2019. 
Schematismus Universi Saecularis er Regularis Cleri Archi Diaeceseos Metrol. Rit. Lat., Leopoli 1936.

Stownik geograficzny Królestwa Polskiego i innych krajów słowiańskich, t. VI, Warszawa 1885.

Stownik geograficzny Królestwa Polskiego i innych krajów słowiańskich, t. XV, część II, Warszawa 1902.

Smirnow J., Mieczystaw Potocki - organizator urzędu konserwatorskiego w Galicji Wschodniej, Kurier Galicyjski, 31 V-16 VI 2014, nr 10.

Stupnicki H., Geograficzno-statystyczny opis Królestwa Galicji i Lodomerii, Lwów 1864.

Szematyzm Królestwa Galicji i Lodomerii z Wielkim Księstwem Krakowskim, Lwów 1914. Szematyzm Szkót Ludowych zostajacych pod nadzorem Lwowskiego Konsystorza Metropolitalnego Obrzadku Łacińskiego na rok 1864, Lwów 1864.

Szematyzm Szkót Ludowych zostajacych pod nadzorem Lwowskiego Konsystorza Metropolitalnego Obrządku Łacińskiego na rok 1867, Lwów 1867.

Tragiczna śmierć dyr. fabryki, Wiek Nowy, 6 I 1933, nr 9470.

W obronie Lwowa i Kresów Wschodnich. Polegli od 1-go listopada 1918 do 30 czerwca 1919 r., Lwów 1926.

\section{Summary \\ The cemetery in Navaria near Lvov: research into the Polish national heritage in the lost Eastern Territories}

Navaria near Lvov has a long history. It was a town during the First Polish Republic $\left(15^{\text {th }}\right.$ $-18^{\text {th }} \mathrm{c}$.) and under the Austrian rule $\left(18^{\text {th }}-19^{\text {th }} \mathrm{c}\right.$.). In the Interwar period, it did not enjoy town privileges and was a village. It remains a large village near Lvov. It made a name for itself in the early $19^{\text {th }}$ century owing to craft weaving. Its inhabitants were also involved in trading and farming. Across centuries, until expatriation following WWII, a majority of Navaria's inhabitants were Catholic Poles. Most probably, during the First Polish Republic, the local Poles were buried in the church cemetery in Navaria. During the Austrian rule, as a result of a new sanitary law, a cemetery was established outside the village, along a road leading to Hodovytsia. The cemetery is still in operation. By 1946, when a majority of Polish families left Navaria, there were numerous Polish graves in the local cemetery. After WWII, a large part of the crosses and headstones with Polish inscriptions disappeared. 
Nadesłany: 2 VII 2020

Nadesłany po poprawkach recenzyjnych: 22 VI 2021

Zaakceptowany: 30 VI 2021

Prof. dr hab. Ryszard Tomczyk

Uniwersytet Szczeciński

Instytut Historyczny

Krakowska 71-79

71-017 Szczecin

e-mail: rtomczyk10@wp.pl

Kościół rzymskokatolicki w Nawarii (fot. dr Barbara Patlewicz)

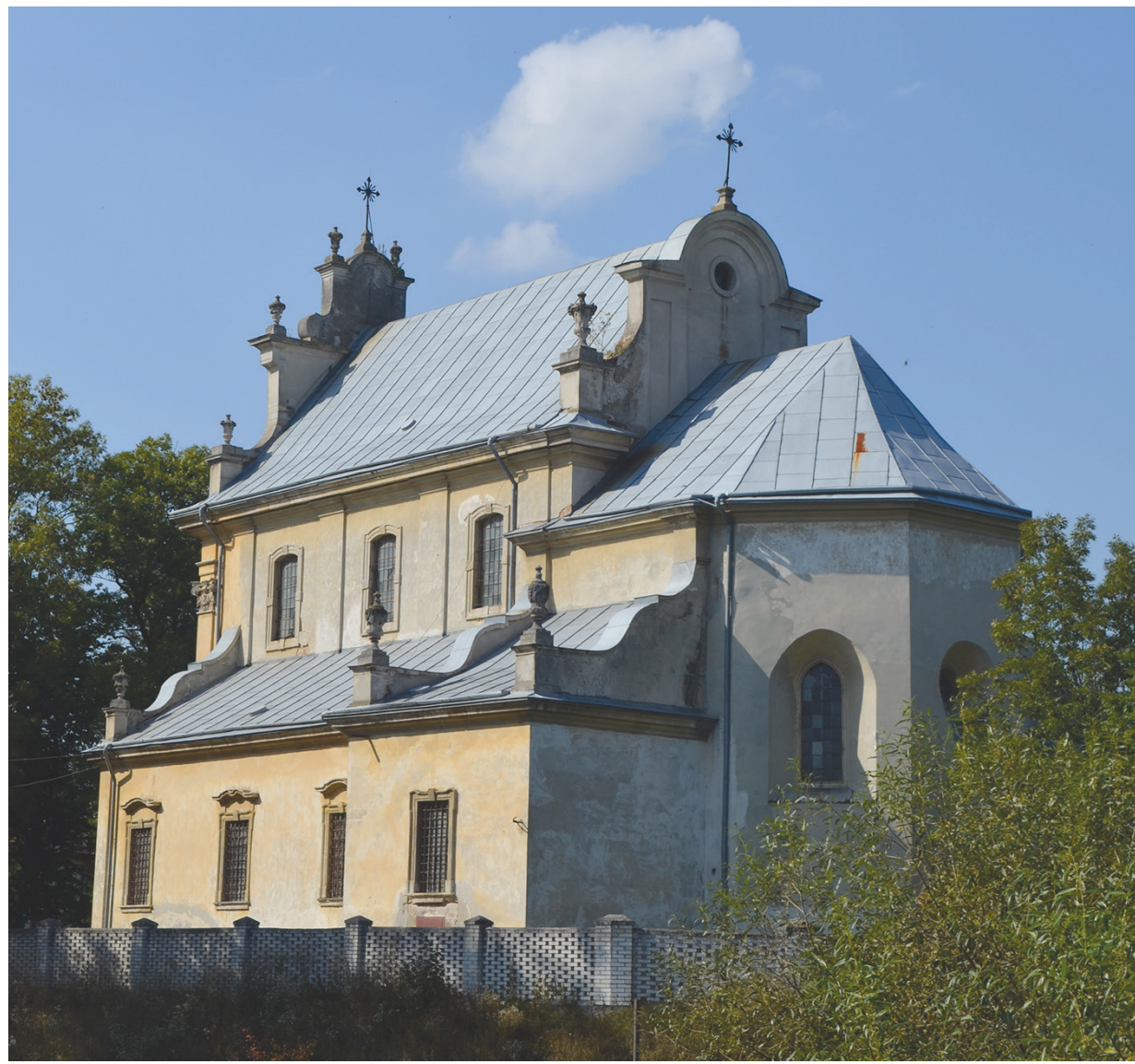


Dzwonnica obok kościoła (fot. dr Barbara Patlewicz)

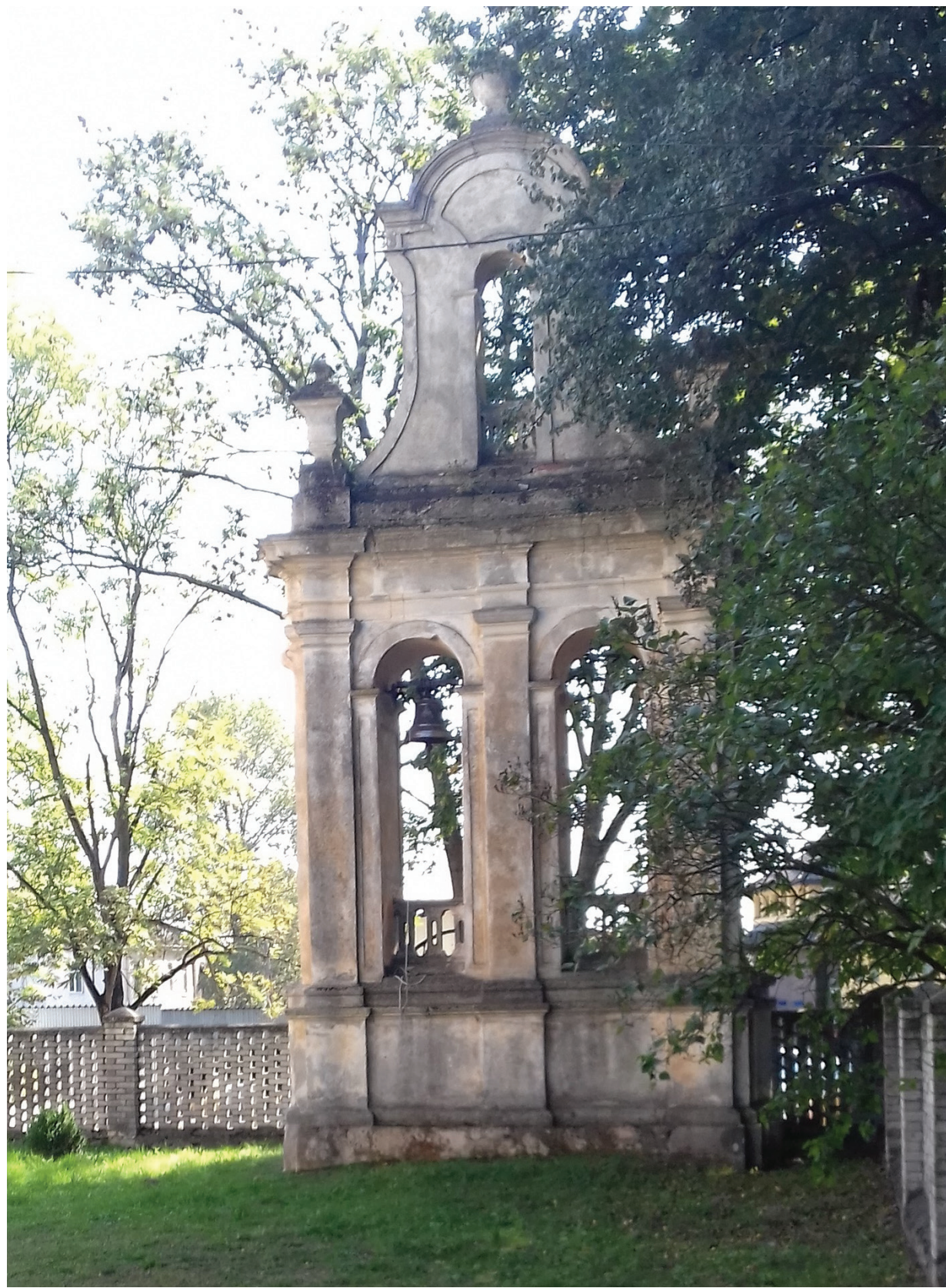


Zniszczona kaplica grobowa na cmentarzu (fot. dr Barbara Patlewicz)

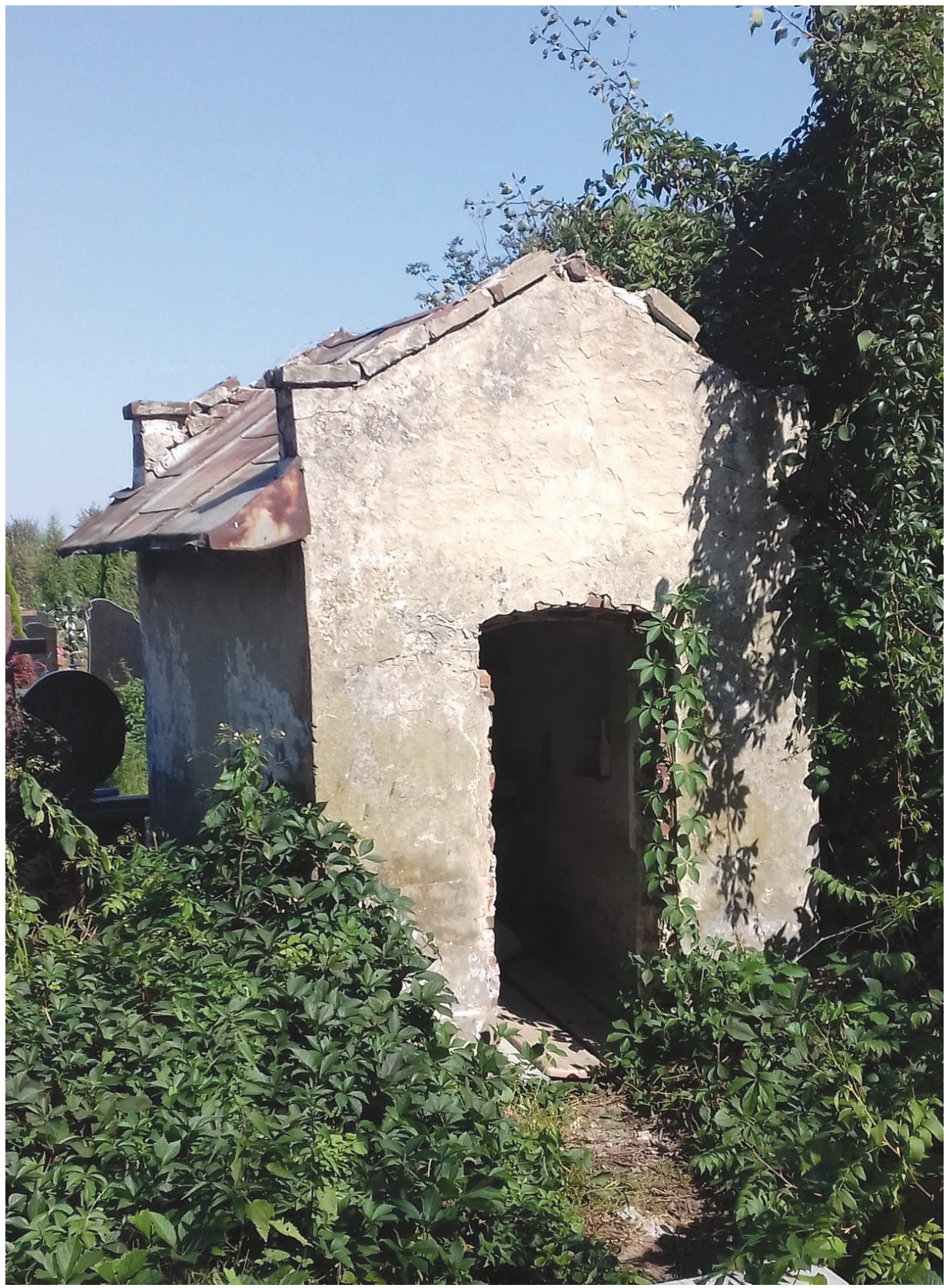


Nagrobki upamiętniające Polaków na historycznej części cmentarza (fot. dr Barbara Patlewicz)

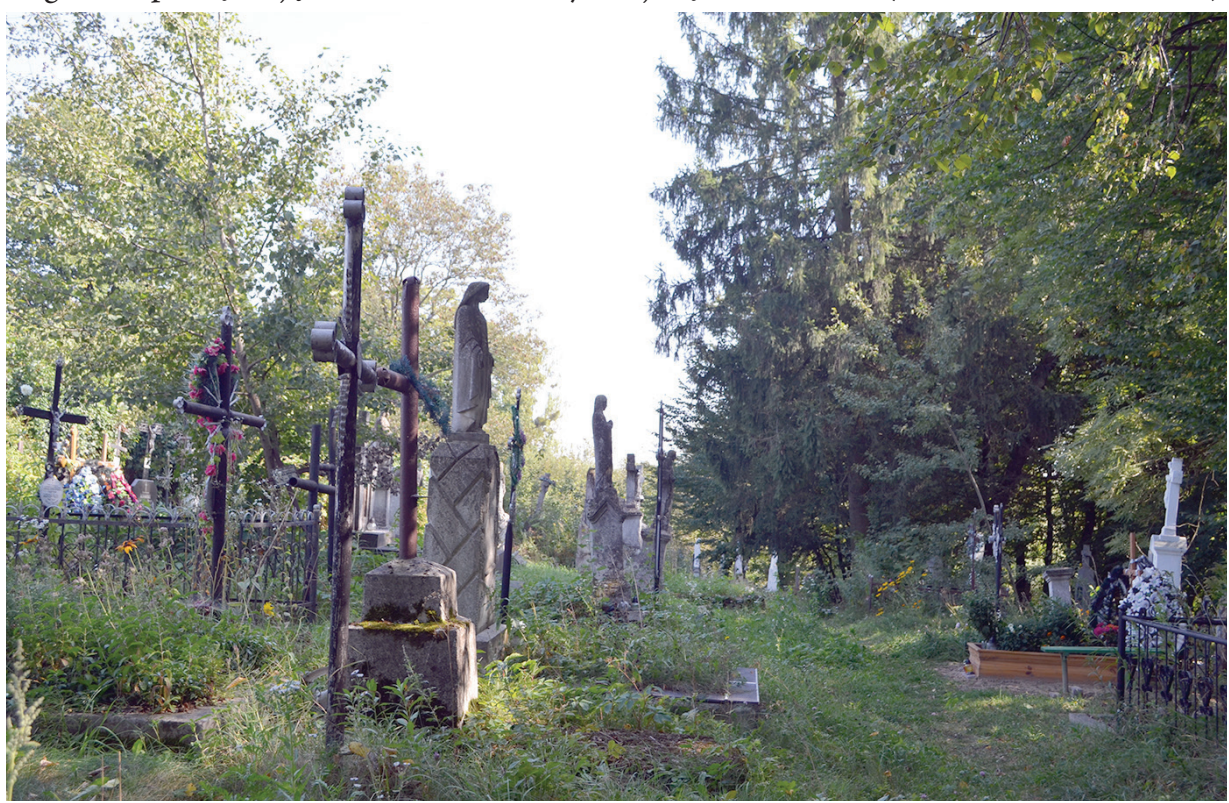

Nagrobki upamiętniające Polaków na historycznej części cmentarza (fot. Barbara dr Patlewicz)

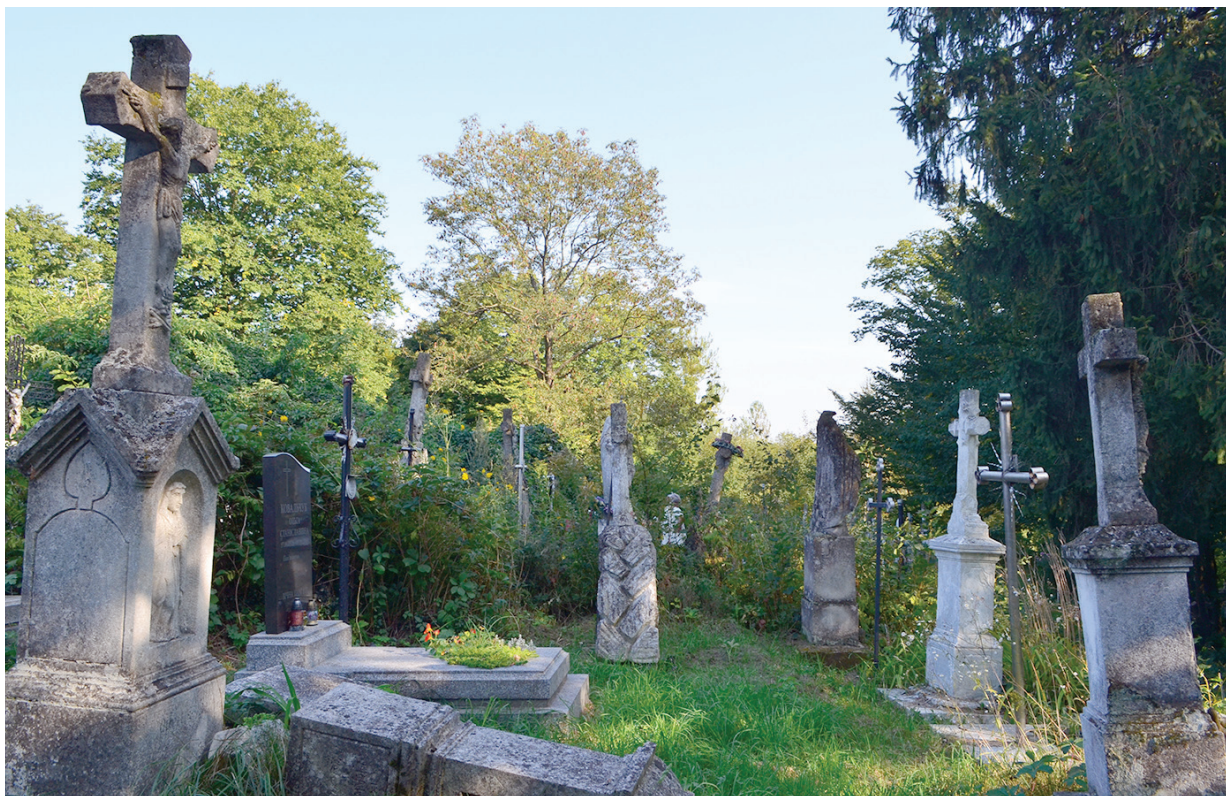


Nagrobki upamiętniające Polaków na historycznej części cmentarza (fot. Barbara dr Patlewicz)

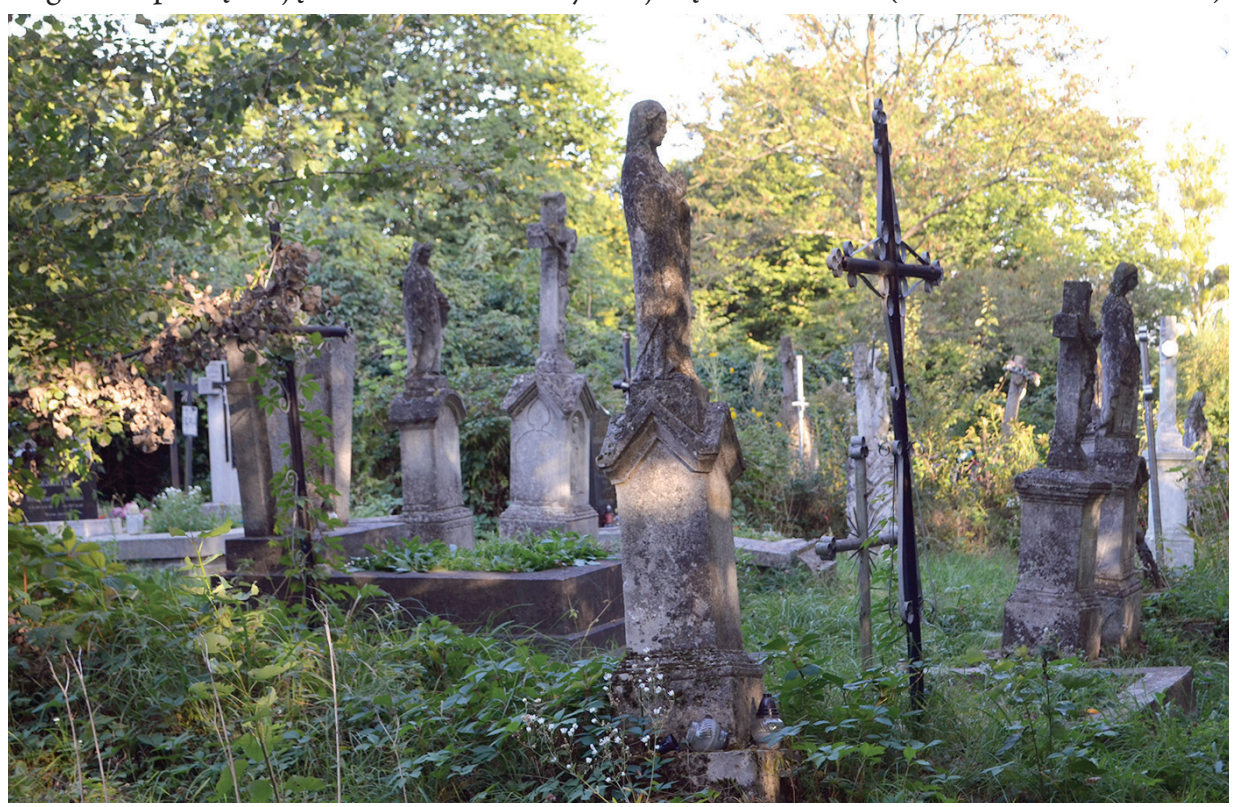

